\title{
VIEWPOINT
}

\section{Expanding the Vision of Quality and Safety in Genomic Medicine}

\author{
Katrina A. Armstrong, $M D, M S^{1,2}$ \\ 'Department of Medicine, Massachusetts General Hospital, Boston, MA, USA; ${ }^{2}$ Harvard Medical School, Boston, MA, USA.
}

J Gen Intern Med 37(2):453-5

DOI: $10.1007 / \mathrm{s} 11606-021-07045-4$

(C) Society of General Internal Medicine 2021

$\mathrm{T}$ he translation of information on genomic variation into clinical care is accelerating. Genomic information is now used to guide risk assessment, diagnosis, and treatment in many areas of medicine. Ordering a genomic test is commonplace in oncology and becoming the standard of care for conditions from developmental disabilities to heart transplant rejection. ${ }^{1,2}$ Over 26 million people in the USA have purchased a genomic test online with a growing proportion interested in their risk of common diseases like cancer, dementia, and heart disease. Given this exponential growth, it is time to expand the vision of genomic quality of care beyond the accuracy of genetic tests to include the clinical processes that determine how these tests are used.

Quality and safety efforts in genomic medicine to date have focused on the validity of genomic tests - particularly analytic validity (ability of the test to measure the genetic variation) and clinical validity (ability of the test result to predict the clinical outcome of interest). Most clinical genomic tests are laboratory-developed tests (LDT), which are regulated by the Clinical Laboratory Improvement Amendments Program (CLIA) at the Center for Medicare and Medicaid Services (CMS). CLIA requires demonstration of analytic validity in a specific laboratory, including result reproducibility and test sensitivity and specificity if possible. It does not require assessment of clinical validity or making information on analytic validity publicly available. A few genomic tests have gone through the FDA approval process that requires demonstration of analytic and clinical validity information that is then released publicly.

Despite the attention to date, more needs to be done to ensure the quality of genomic tests. ${ }^{3}$ Lack of reproducibility of the same test across labs raises questions about the accuracy of testing in any given lab. Inadequate availability of information about test sensitivity and specificity can lead to diagnostic

Received April 12, 2021

Accepted July 14, 2021

Published online August 6, 2021 error if the clinician misunderstands the impact of a test result on the probability of a diagnosis. Concerns about LDTs led to a 2014 FDA proposal to expand their authority to regulate the market entry of LDT. However, this proposal was controversial in the laboratory medicine community because of the potential impact on test innovation and patient access to diagnostic services. Whether the solution to the quality of genomic tests lies with the FDA, CMS, or elsewhere, high-quality genomic medicine requires high-quality information about the accuracy of genomic tests (including reproducibility and sensitivity and specificity) being available to physicians and patients.

While effective oversight of the quality of genomic tests is necessary for high-quality genomic medicine, it is far from sufficient. The quality of genomic medicine also depends upon how tests are used, including who should undergo testing, what testing approach should be selected, how the test results should be interpreted, how the patient and family should be counseled, and how test results should be applied to clinical decisions (Table 1). Each of these steps reflects one or more of the six quality domains defined by the National Academy of Medicine: safety, effectiveness, timeliness, patient centeredness, efficiency, and equity. ${ }^{4}$ Each step raises specific quality concerns, potential strategies for quality improvement, and potential quality metrics. Quality improvement strategies include clinical decision support at the point of care, population health management through the creation of registries and outreach to patients who have not received the appropriate test or treatment, root cause analysis of errors, and creation of training and performance standards for providers. Quality metrics are concentrated in outcome and process measures as little is known about the structural characteristics that lead to high quality in each of these steps. These include compliance with testing and treatment guidelines, rates of diagnosis, diagnostic error and additional testing, patientreported outcomes including understanding of test results, provider competency assessment, and unexplained differences in each area across patient sociodemographic characteristics like race/ethnicity.

The implementation of this model will require the development of practice guidelines for the use of genomic applications in specific clinical scenarios. Fortunately, several specialty organizations are already engaged in this effort. The American Society of Clinical Oncology and the National Comprehensive Cancer Network have created multiple guidelines for the use 
Table 1 Approach to Quality of Care in Genomic Medicine

\begin{tabular}{|c|c|c|c|c|}
\hline & $\begin{array}{l}\text { NAM quality } \\
\text { domain }\end{array}$ & Quality concern & $\begin{array}{l}\text { Possible quality improvement } \\
\text { strategies }\end{array}$ & Possible quality metrics \\
\hline Who should be tested? & $\begin{array}{l}\text { Effectiveness, } \\
\text { equity }\end{array}$ & $\begin{array}{l}\text { Overuse and underuse of } \\
\text { testing }\end{array}$ & $\begin{array}{l}\text { Clinical decision support, process } \\
\text { improvement, population health } \\
\text { management }\end{array}$ & $\begin{array}{l}\text { Compliance with testing } \\
\text { guidelines, disparities in testing }\end{array}$ \\
\hline $\begin{array}{l}\text { How should the } \\
\text { patient be counseled? }\end{array}$ & $\begin{array}{l}\text { Patient } \\
\text { centeredness, } \\
\text { efficiency }\end{array}$ & $\begin{array}{l}\text { Inadequate patient } \\
\text { understanding and } \\
\text { engagement }\end{array}$ & $\begin{array}{l}\text { Training and performance } \\
\text { standards, simulation }\end{array}$ & $\begin{array}{l}\text { Patient satisfaction and } \\
\text { understanding }\end{array}$ \\
\hline $\begin{array}{l}\text { What testing approach } \\
\text { should be used? }\end{array}$ & $\begin{array}{l}\text { Effectiveness, } \\
\text { efficiency }\end{array}$ & $\begin{array}{l}\text { Diagnostic or prognostic } \\
\text { error }\end{array}$ & $\begin{array}{l}\text { Clinical decision support, root } \\
\text { cause analyses }\end{array}$ & $\begin{array}{l}\text { Compliance with testing } \\
\text { guidelines, diagnostic yield, rates } \\
\text { of additional testing }\end{array}$ \\
\hline $\begin{array}{l}\text { How should test } \\
\text { results be interpreted? }\end{array}$ & $\begin{array}{l}\text { Safety, } \\
\text { effectiveness }\end{array}$ & $\begin{array}{l}\text { Diagnostic or prognostic } \\
\text { error }\end{array}$ & $\begin{array}{l}\text { Clinical decision support, root } \\
\text { cause analyses }\end{array}$ & $\begin{array}{l}\text { Diagnostic error rates, provider } \\
\text { competency assessment }\end{array}$ \\
\hline $\begin{array}{l}\text { How should test } \\
\text { results be used in } \\
\text { clinical care? }\end{array}$ & $\begin{array}{l}\text { Effectiveness, } \\
\text { timeliness, equity }\end{array}$ & $\begin{array}{l}\text { Overuse and underuse of } \\
\text { follow-up testing and treat- } \\
\text { ments }\end{array}$ & $\begin{array}{l}\text { Clinical decision support, process } \\
\text { improvement, population health } \\
\text { management }\end{array}$ & $\begin{array}{l}\text { Compliance with treatment } \\
\text { guidelines, disparities in } \\
\text { treatment }\end{array}$ \\
\hline
\end{tabular}

of genomic applications in cancer. The American College of Obstetrics and Gynecology Committee on Genetics provides guidance for the use of genomic testing in several settings, including prenatal screening. The US Preventive Services Task Force (USPSTF) now includes genetic testing for disease risk in its scope. However, other specialty organizations have been less engaged even as genomic tests become part of the diagnosis and management of conditions in their fields. Of the American Heart Association's 675 guidelines, only four reference genetics. ${ }^{5}$ Reference to genetics is equally difficult to find in the guidelines produced by KDIGO (Kidney Disease: Improving Global Outcomes). ${ }^{6}$ Engagement of these and other specialty organizations will be needed. Such engagement will require developing comfort with using analytic frameworks and a range of evidence to guide recommendations as randomized controlled trials of genomic tests will be uncommon.

In addition to these specialty-specific guidelines, genomic medicine raises several relatively unique quality issues that cut across specialties including use and configuration of genetic counseling, family implications of test results for family members, management of test results that have implications for multiple diseases across specialty areas and need to reinterpret sequencing results as new information becomes available about pathogenicity of genetic variants. In each area, efforts are needed to define the optimal structure and process across different clinical and practice settings, decide upon appropriate outcomes, and develop approaches for ongoing quality assessment and improvement. ${ }^{7}$ Given the centrality of these issues to medical genetics and the American College of Medical Genetics (ACMG) engagement in establishing laboratory standards for genomic testing and interpretation, the ACMG could lead such efforts, including the coordination with specialty societies. Alternatively, a federal effort could be developed aligned with the current Precision Medicine Initiative.

Genomic medicine also raises specific equity issues. Accurate genomic tests depend upon the ability to interpret a genetic sequence, which in turn depends upon the availability of appropriate reference data. Because genetic research initially concentrated in populations of European ancestry, data on variation in other ancestral groups has been limited, reducing the accuracy and potential benefits of testing in these groups. ${ }^{8}$ At the same time, uptake of testing has been lower among people of color in many settings, at least in part because of insufficient access to appropriate specialists, inadequate insurance coverage, and lower rates of physician recommendations for testing. The growing attention to these issues has led to major initiatives to improve the ancestral diversity of biobanks and other reference genomic data, an important step forward in this area. ${ }^{9}$ However, national attention is needed to improve access to genomic services, perhaps through efforts such as the Healthy People Initiative, so that inequity in genomic medicine does not worsen disparities in other areas.

The last forty years have seen major advances in genomics. While the laboratory genetics community has focused on advancing the accuracy of genetic tests, relatively little attention has been paid to the broader quality issue of how those tests are used in clinical practice. Integrating the clinical practice of genomic medicine into quality and safety efforts will be critical for realizing the potential benefit of human genomics for human health.

Corresponding Author: Katrina A. Armstrong, MD, MS; Department of Medicine, Massachusetts General Hospital, Boston, MA, USA (e-mail: karmstrong6@mgh.harvard.edu).

\section{Declarations:}

Conflict of Interest: Dr. Armstrong has no relevant conflicts of interest.

\section{REFERENCES}

1. Agbor-Enoh S, Shah $\mathbf{P}$, Tunc $\mathbf{I}$, et al. Cell-Free DNA to Detect Heart Allograft Acute Rejection. Circulation. 2021;143(12):1184-1197.

2. Lipkin PH, Macias MM, Council On Children With Disabilities, Section On Developmental and Behavioral Pediatrics. Promoting Optimal Development: Identifying Infants and Young Children With Developmental 
Disorders Through Developmental Surveillance and Screening. Pediatrics. 2020; 145(1):e20193449.

3. Evans BJ, Javitt G, Hall R, et al. How Can Law and Policy Advance Quality in Genomic Analysis and Interpretation for Clinical Care? J Law Med Ethics. 2020;48(1):44-68.

4. Committee on Quality of Health Care in America, Institute of Medicine. Crossing the Quality Chasm: A New Health System for the 21st Century. 2001.

5. American Heart Association Guidelines and Statements. American Heart Association. https://professional.heart.org/professional/ GuidelinesStatements/UCM_492626_Guidelines-Statements-Search-Page. jsp. Accessed 10 May 2021.

6. KDIGO Guidelines. KDIGO. https://kdigo.org/guidelines/. Accessed 10 May 2021
7. Williams MS. Quality in clinical genetics. Am J Med Genet C Semin Med Genet. 2009;151C(3):175-178.

8. Landry LG, Rehm HI. Association of Racial/Ethnic Categories With the Ability of Genetic Tests to Detect a Cause of Cardiomyopathy. JAMA Cardiol. 2018;3(4):341-345.

9. Abul-Husn NS, Kenny EE. Personalized Medicine and the Power of Electronic Health Records. Cell. 2019;177(1):58-69.

Publisher's Note: Springer Nature remains neutral with regard to jurisdictional claims in published maps and institutional affiliations. 